\title{
ARTICLE
}

\section{Evaluation of genotype $x$ environment interactions in maize hybrids using GGE biplot analysis}

\author{
Fatma Aykut Tonk ${ }^{1 *}$, Emre Ilker ${ }^{1}$ and Muzaffer Tosun ${ }^{1}$
}

Received 8 January 2010

Accepted 8 September 2010

\begin{abstract}
Seventeen hybrid maize genotypes were evaluated at four different locations in 2005 and 2006 cropping seasons under irrigated conditions in Turkey. The analysis of variance showed that mean squares of environments $(E)$, genotypes $(G)$ and GE interactions (GEI) were highly significant and accounted for 74,7 and $19 \%$ of treatment combination sum squares, respectively. To determine the effects of GEI on grain yield, the data were subjected to the GGE biplot analysis. Maize hybrid G16 can be proposed as reliably growing in test locations for high grain yield. Also, only the Yenisehir location could be best representative of overall locations for deciding about which experimental hybrids can be recommended for grain yield in this study. Consequently, using of grain yield per plant instead of grain yield per plot in hybrid maize breeding programs could be preferred by private companies due to some advantages.
\end{abstract}

Key words: corn, grain, yield, mega-environments.

\section{INTRODUCTION}

Maize (Zea mays L.) is the third most important cereal food crop of the world after wheat and rice (Poehlman 1979). Hybrid maize cultivars are grown in approximately 500.000 hectares annually in majority maize production areas of Turkey. Maize production is carried out mostly in Marmara (Marmora) in North Western, Ege (Aegean) in Western and Akdeniz (Mediterranean) in Southern Regions of Turkey. Newly improved hybrid maize cultivar candidates by private seed companies need to be tested at many locations and for several years before being recommended to grow in a given location. Multi-environment yield trials evaluated in terms of plot yield are used in the final selection cycles to identify superior hybrid maize cultivar candidates in maize breeding programs. On the other hand, some researchers consider plant yield individually instead of plot yield to predict grain yield per area (Tollenaar et al. 2004, Carena 2005, Boomsma et al. 2009). Although both methods are used in hybrid maize breeding programs, harvesting of single plant may have some advantages in terms of time consuming, labor and cost.

Evaluation of genotypic performances of hybrid maize cultivar candidates in a number of environments provides useful information to identify their adaptation and stability (Crossa 1990). Kang et al. (1991) indicated that selection based on yield only may not always be adequate when genotype $\mathrm{x}$ environment interaction is significant. In addition, they proposed that the use of a rank-sum method is an alternative when testing is done in diverse environments.

Genotype $\mathrm{x}$ environment interaction in multienvironment trials refers to differential responses of genotypes across a range of environments (Kang 1998).

\footnotetext{
${ }^{1}$ Ege University, Faculty of Agriculture, Department of Field Crops, Bornova-Ýzmir, Turkey. *E-mail: fatma.aykut@ege.edu.tr
} 
FA Tonk et al.

Most important agronomical and economical traits such as grain yield, are quantitative in nature and routinely exhibit genotype $x$ environment interaction (Fan et al. 2007) Genotype $x$ environment interactions determined in multi location trials reduced the correlation between phenotypic and genotypic values and have been found to reduce gain from selection (Comstock and Moll 1963). The development of maize hybrids which are high-yielding and relatively stable when grown in different environments is of fundamental importance to commercial maize production (Gama and Hallauer 1980). At the same time, Scott (1967) explained that yield stability in maize is under genetic control and, thus, suitable for selection.

There have been many attempts to analyze genotype $\mathrm{x}$ environment interaction for registered varieties of maize hybrid under different environments. Signor et al. (2001) interpreted that genotype $\mathrm{x}$ environment interaction was investigated for grain yield of 132 early maize hybrids in 229 environments over 12 years. They expressed that flowering earliness of hybrids, water balance around flowering and mean temperature from the 12 leaf stage to the end of the grain filling phase were determinants of genotype $\mathrm{x}$ environment interaction for grain yield in the considered area. Kang and Gorman (1989) implied that the 17 hybrid maize cultivars evaluated in their study were more affected by differential fertility or cultural practices than by the weather factors. They concluded that none of them significantly affected genotype $\mathrm{x}$ environment interaction for corn yield. Giauffret et al. (2000) showed yield instability to the genotype $\mathrm{x}$ environment interactions observed for vegetative or flowering traits, and determined the response of these vegetative or flowering traits to temperature and photoperiod in maize hybrids. Besides, Oliveira et al. (2003) stated that most maize hybrids demostrated low contribution to genotype $\mathrm{x}$ environment interaction, although the single crosses presented greater mean yield, and the double hybrids showed greater yield stability for ten environments in Central Brazil.

GGE (genotype + genotype-by-environment interaction) biplot analysis is used to identify some of the least discriminating locations and representing test locations (Fan et al. 2007). The same researchers implied that the GGE biplot methodology was a useful tool for identifying locations that optimized the cultivars performance and for making better use of limited resources available for the testing program. Also, Dehghani et al. (2009) proposed that the GGE biplot method can be used to identify superior maize genotypes for target sites in
Iran. Furthermore, Balestre et al. (2009) indicated that the GGE biplot analysis was superior to the graph AMMI1 mega-environment for being more efficient in explaining the sum of squares of GE and G + GE, due to confirmed by its greater predictive accuracy in maize hybrids.

Our objectives were to investigate the stability of performance for grain yield using single plant of some hybrid maize candidates tested across a number of environments under Mediterranean conditions in Turkey via the GGE biplot software (Yan 2001). The information generated at the end of the study can be useful for plant breeders for the pre-selection of experimental hybrids in maize breeding programs.

\section{MATERIAL AND METHODS}

Seventeen maize genotypes (Table 1) were evaluated at four locations (Yenişehir-Marmora Region; BornovaAegean Region; Ceyhan-Mediterranean Region; SeyhanMediterranean Region) in 2005 and 2006 cropping seasons under irrigated conditions. A randomized complete block design with three replications was used. Each plot had four rows of $5 \mathrm{~m}$ lengths with spacing of $70 \mathrm{~cm}$ between rows and $18 \mathrm{~cm}$ between plants within row. Two seeds were planted per hill and then thinned to one plant per hill to have a final plant 79,286 plants ha- ${ }^{-1}$. To reduce border effects, plant samples were taken from the two central rows

Table 1. Genotype code and name of hybrid maize cultivars and experimental hybrids in the trials

\begin{tabular}{cll}
\hline Genotype code & Name & Hybrid Definition \\
\hline G1 & SX896 & Experimental Hybrid \\
G2 & SX897 & Experimental Hybrid \\
G3 & SX880 & Experimental Hybrid \\
G4 & RX9292 (C) & Check Hybrid \\
G5 & SX825 & Experimental Hybrid \\
G6 & SX829 & Experimental Hybrid \\
G7 & SX733 & Experimental Hybrid \\
G8 & SX731 & Experimental Hybrid \\
G9 & SX885 & Experimental Hybrid \\
G10 & SX886 & Experimental Hybrid \\
G11 & SX883 & Experimental Hybrid \\
G12 & P31G98 (C) & Check Hybrid \\
G13 & SX813 & Experimental Hybrid \\
G14 & SX847 & Experimental Hybrid \\
G15 & SHEMAL (C) & Check Hybrid \\
G16 & SX891 & Experimental Hybrid \\
G17 & SX882 & Experimental Hybrid \\
\hline
\end{tabular}


of each plot. Fourteen experimental hybrids developed by MayAgro Seed Corporation (Private Company) and three check maize hybrid cultivars were included in this study.

The locations where the experiment was conducted were different in soil type and mean seasonal rainfall (Table 2). Also the years differentiated in terms of mean seasonal rainfall. Therefore, locations in each year were considered as different environments because the locations, years and location $\mathrm{x}$ year interaction were determined significantly (Table 4). Besides, temperature and relative humidity didn't vary in both the locations and the years. Several traits were assessed but only data for grain yield per plant (g/plant, at $15.0 \%$ grain moisture) was obtained on the basis of two rows, was reported here. Measurements for grain yield per plant were taken on ten competitive plants within each plot of the hybrid maize genotypes.

Table 2. Seasonal rainfall and soil type of the test locations in 2005 and 2006

\begin{tabular}{lccl}
\hline \multirow{2}{*}{ Locations } & \multicolumn{2}{c}{ Seasonal rainfall ${ }^{*}$ (mm) } & \multirow{2}{*}{ Soil type } \\
\cline { 2 - 3 } & $\mathbf{2 0 0 5}$ & $\mathbf{2 0 0 6}$ & \\
\hline Adana-Seyhan & (S5) 28.4 & (S6) 18.7 & Clay loam \\
İzmir-Bornova & (B5) 21.2 & (B6) 40.2 & Silty clay \\
Adana-Ceyhan & (C5) 26.9 & (C6) 13.3 & Clay \\
Bursa-Yenişehir & (Y5) 52.9 & (Y6) 27.9 & Clay \\
\hline
\end{tabular}

* Mean rainfall during April to October.

Combinations of years (2005 and 2006) and four locations were treated as eight environments. To determine the effects of genotype $\mathrm{x}$ environment interaction for grain yield, the data (Table 3) were first subjected to ANOVA (Analysis of variance) analysis. Then GGE biplot software (Yan 2001) was used to graphically show the genotypes and environments. Angles between environment vectors were used to judge correlations (similarities/dissimilarities) between pairs of environments (Yan and Kang 2003). A GGE distance was computed and correlated with yieldstability statistic $\left(\mathrm{YS}_{\mathrm{i}}\right)$.

\section{RESULTS AND DISCUSSION}

Currently, almost all maize cultivars grown in Turkey are single cross hybrids. The main reason for transition from heterogeneous stands of open-pollinated varieties to homogeneous stands of single-cross hybrids during the last decade has higher mean yield of single cross hybrid cultivars. Selecting a hybrid cultivar for diverse maize growing areas of Turkey requires that maize growers consider stability of performance in addition to an average or maximum performance.

The mean grain yield of the hybrid maize genotypes was given in Table 3 and the maximum plant yield values at each environment were underlined. Analysis of variance was constructed to determine the effects of environments (E), genotypes ( $\mathrm{G}$ ) and genotype $\mathrm{x}$ environment interactions (GEI). The results of combined analysis of grain yield were shown in Table 4. It appeared that the grain yields of the hybrid maize genotypes were significantly affected by environment which explained $74 \%$ of the total variation $(\mathrm{G}+\mathrm{E}+\mathrm{GEI})$, whereas genotype and genotype $\mathrm{x}$ environment interaction which accounted for $7 \%$ and $19 \%$, respectively (Table 4). Also, the partitioning of GGE through GGE biplot analysis showed that the first 2PCs explained $61.2 \%$ of total variance ( $34.8 \%$ and 26.41 by $\mathrm{PC} 1$ and $\mathrm{PC} 2$, respectively) (Table 5).

Visualization of the which-won-where pattern of multi-environment yield trials data may reveal the different mega environments in a region. The polygon is drawn by connecting the vertex genotypes that are further away from the biplot origin. The rays in Figure 1 were formed as perpendicular to the sides of the polygon or their extensions. Ray 1 was perpendicular to the side that connects genotypes G15 and G17; Ray 2 was perpendicular to extension of G9 and G17; Ray 3 was perpendicular to side G9 and G10; similarly, Ray 4 was perpendicular to side G10 and G5; Ray 5 to side G5 and G12; Ray 6 to side G12 and G15. These six rays divided the biplot into 6 sectors and five environments fell into sector 2, two environments fell into sector 6 and one environment fell into sector 5 (Figure 1).

Figure 1 indicates that there exists one possible hybrid maize mega environment in hybrid maize tested areas represented by genotypes G17 and G9 for grain yield per plant. This mega environment (Yenişehir location, Y5 in 2005 and Y6 in 2006) corresponded to environments and genotypes falling into sector 2. Also, this mega environment pattern for grain yield needs verifying through multi-year and environment experiments. Indeed, it has been known that some private hybrid maize seed companies (Monsanto, Cargill, AgroMar, Limagrain etc.) have carried out their hybrid maize yield trials in the same sites (Yenişehir and Ceyhan) of this mega environment.

Grain yield performances and stability of genotypes are examined by an average environment coordination method (Yan 2002). An average environment is demonstrated by using average PC1 and PC2 scores of all environments, indicated by a small circle (Figure 2). A line is then drawn to 
FA Tonk et al.

Table 3. Mean grain yields $\left(\mathrm{kg} \mathrm{ha}^{-1}\right)$ converted from grain yield per plant of 17 maize genotypes tested in 8 environments

\begin{tabular}{cccccccccc}
\hline $\begin{array}{c}\text { Genotypes } \\
\text { Code }\end{array}$ & \multicolumn{7}{c}{ Environments } \\
\cline { 2 - 10 } S5 & B5 & C5 & Y5 & S6 & B6 & C6 & Y6 & Mean \\
\hline G1 & 13224.1 & 16517.7 & 16544.6 & 16792.8 & 14573.6 & 16517.7 & 14667.9 & 17997.9 & 15854.5 \\
G2 & 13278.8 & 17971.8 & 16491.5 & 16482.8 & 13077.4 & 17310.5 & 13724.4 & 18182.7 & 15815.0 \\
G3 & 13967.8 & 17839.4 & 16623.9 & 16135.5 & 14063.8 & 15989.6 & 13415.2 & 17205.1 & 15655.0 \\
G4 & 10199.4 & 17706.9 & 17151.9 & 17910.7 & 14426.9 & 18368.2 & 15050.1 & 16941.0 & 15969.4 \\
G5 & 13699.0 & 15460.8 & 16253.6 & 15784.3 & 12438.4 & 17706.9 & 12277.4 & 16306.8 & 14990.9 \\
G6 & 13564.2 & 18499.8 & 17046.5 & 16846.7 & 13910.7 & 16386.0 & 15153.9 & 16755.5 & 16020.4 \\
G7 & 13395.4 & 17706.9 & 16834.8 & 16475.6 & 14276.2 & 18447.5 & 13558.7 & 16359.1 & 15881.8 \\
G8 & 13331.9 & 18235.8 & 16623.9 & 16300.4 & 12135.5 & 16386.0 & 13035.4 & 16650.1 & 15337.4 \\
G9 & 12904.6 & $\underline{\mathbf{1 9 1 6 1 . 0}}$ & 18447.5 & 20188.6 & 12218.8 & 18368.2 & 12345.6 & $\underline{\mathbf{1 9 5 5 7 . 5}}$ & 16649.0 \\
G10 & 11549.6 & 18103.4 & 16967.2 & 16747.6 & 11251.5 & 18632.2 & 11317.3 & 16544.6 & 15139.2 \\
G11 & 12007.9 & 18235.8 & 16861.8 & 16894.3 & 13072.7 & 16914.1 & 12879.2 & 16703.2 & 15446.1 \\
G12 & $\underline{\mathbf{1 5 0 2 6 . 3}}$ & 18235.8 & 16755.5 & 16098.2 & 16154.5 & $\underline{\mathbf{1 9 1 6 1 . 0}}$ & $\underline{\mathbf{1 6 3 5 2 . 7}}$ & 15857.2 & 16705.2 \\
G13 & 12749.2 & 18235.8 & 17363.6 & 17251.8 & 11294.3 & 18103.4 & 10855.0 & 17548.4 & 15425.2 \\
G14 & 13760.9 & 17178.9 & 16887.9 & $\underline{\mathbf{2 0 3 8 0 . 5}}$ & 12518.5 & 17575.3 & 13596.8 & 18843.9 & 16342.8 \\
G15 & 14120.8 & 16386.0 & 17205.1 & 17947.2 & $\underline{\mathbf{1 6 4 2 5 . 7}}$ & 17971.8 & 15840.5 & 18077.2 & 16746.8 \\
G16 & 14913.7 & 18764.6 & 17548.4 & 17747.4 & 15392.6 & 17310.5 & 14191.4 & 18473.6 & 16792.8 \\
G17 & 12290.9 & 19028.6 & $\underline{\mathbf{1 8 7 3 7 . 7}}$ & 19110.3 & 14358.7 & 16914.1 & 14285.8 & 19002.5 & 16716.1 \\
Mean & 13175.6 & 17839.4 & 17079.1 & 17358.5 & 13622.9 & 17533.1 & 13679.3 & 17470.9 & 15969.9 \\
\hline
\end{tabular}

Underlined values are highest yields at each test environments.

Table 4. Combined analysis of variance of grain yield per plant of 17 hybrid maize genotypes tested across 8 environments

\begin{tabular}{lrrrrr}
\hline Sources of variation & df & \multicolumn{1}{c}{ SS } & \multicolumn{1}{c}{ MS } & \multicolumn{1}{c}{ F } & Explained (\%) \\
\hline Environment (E) & 7 & 242691.410 & 34670.201 & $119.517^{* *}$ & 74 \\
$\quad$ Location (L) & 3 & 194557.609 & 64852.536 & $211.304^{* *}$ & 80 \\
$\quad$ Year (Y) & 1 & 10039.437 & 10039.437 & $32.711^{* *}$ & 4 \\
$\quad$ L x Y & 3 & 38094.364 & 12698.121 & $41.373^{* *}$ & 16 \\
Genotype (G) & 16 & 21931.675 & 1370.730 & $4.725^{* *}$ & 7 \\
GEI & 112 & 65063.593 & 580.925 & $2.003^{* *}$ & 19 \\
Error & 256 & 74262.179 & 290.087 & & \\
Total & 407 & 413179.101 & & & \\
\hline
\end{tabular}

** Significant at the 0.01 level of probability.

Table 5. GGE-biplot analysis of grain yield per plant of 17 hybrid maize genotypes tested across 8 environments

\begin{tabular}{ccc}
\hline $\begin{array}{c}\text { Principal } \\
\text { component }\end{array}$ & $\begin{array}{c}\text { Singular } \\
\text { values }\end{array}$ & $\begin{array}{c}\text { \% of total } \\
\text { variation }\end{array}$ \\
\hline PC1 & 6.677 & 34.8 \\
PC2 & 5.811 & 26.4 \\
PC3 & 4.223 & 13.9 \\
PC4 & 3.392 & 9.0 \\
\hline
\end{tabular}

pass through this average environment and the biplot origin. This line is called the average environment axis and serves as the abscissa of the average environment coordination.
The ordinate of the average environment coordination is the line that passed through the origin and is perpendicular to the average environment coordination abscissa (Figure 2). Average environment coordination abscissa is indicated with one direction arrow and implied the greater genotype main effect. On the other hand, average environment coordination ordinate is shown by double arrows, either directing away from the biplot origin suggests greater genotype $\mathrm{x}$ environment interaction effect and reduced stability. The average environment coordination ordinate distinguishes genotypes with below-average means from 


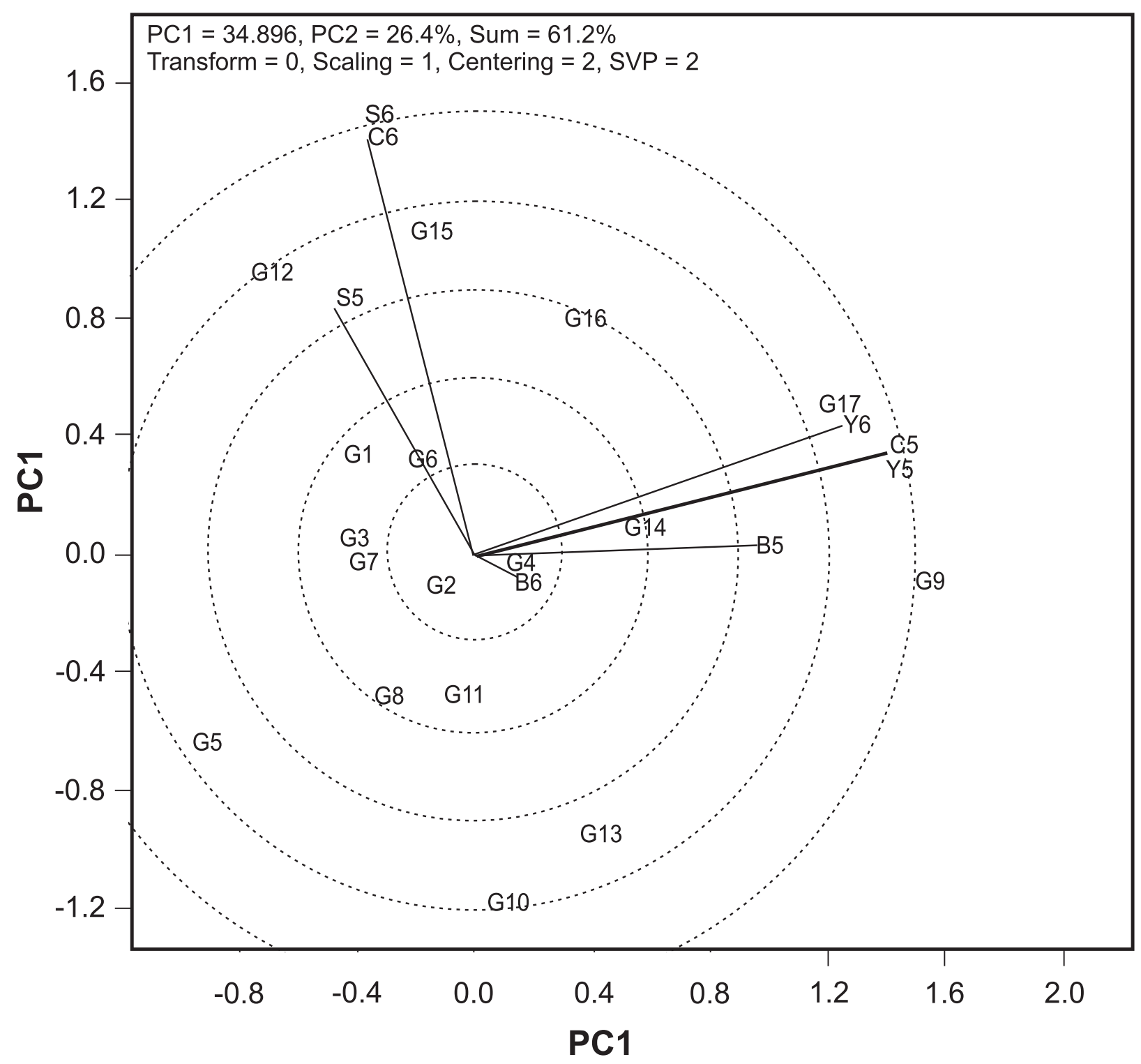

Figure 1. Polygon views of the GGE biplot for the genotype by environment 2-way data.

those with above-average means. Also, the mean grain yield of genotypes is estimated by the projections of their markers to the average environment coordination abscissa (Kaya et al. 2006). Maize hybrids with above mean yield of all genotypes were in between G17 and G4 while genotypes with below-average means changed from G2 to G5. The length of the average environment vector (the distance from biplot origin and the average environment marker) indicates the relative importance of genotype main effect within genotype $x$ environment interaction. If the length of the average environment vector is longer, the genotype main effect within genotype $\mathrm{x}$ environment interaction means more important and more meaningful the selection based on mean performance. In our study, the length of the average environment vector was enough to select hybrid maize genotypes based on grain yield per plant. Genotypes with above-average means could be selected based on mean grain yield. Also genotypic stability is usually important in addition to mean yield of a genotype. A longer projection to the average environment ordinate demonstrates which genotypes are more variable and less stable across environments. Genotypes G16 and G4 were more stable as 
FA Tonk et al.

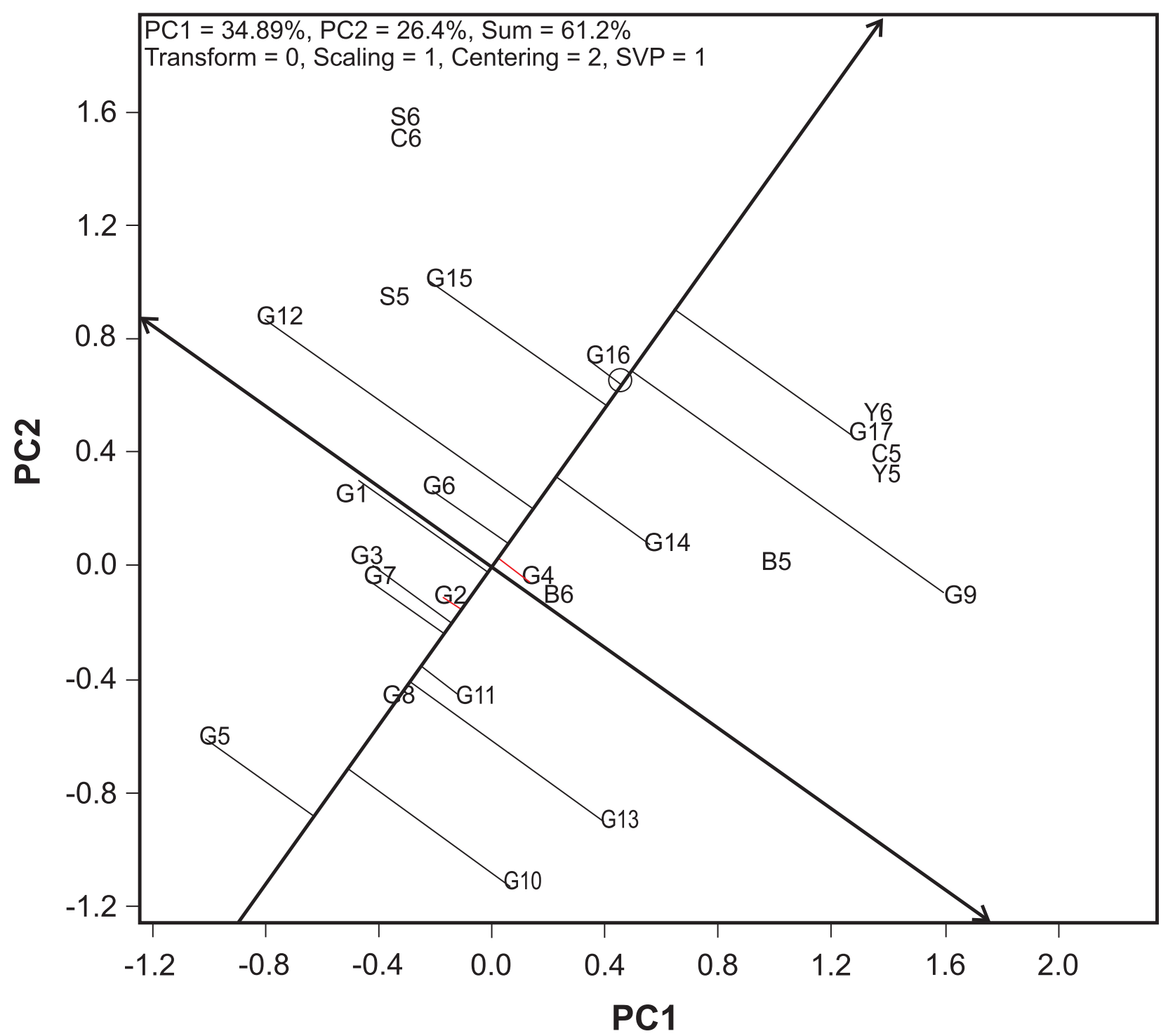

Figure 2. Average environment coordination views of the GGE-biplot based on environment-focused scaling for the mean performance and stability of genotypes.

well as high yielding. Conversely, G9 and G12 were more variable, but high yielding.

An ideal genotype grown in test environments in our study should possess the highest mean performance and absolutely stability. Such an ideal hybrid maize genotype having high plant yielding genotypes and with zero genotypes $x$ environment interaction should be described by having the greatest vector length from origin of biplot to the genotype markers. The highest plant yielding genotypes G9, and G17 were obtained as unstable because they have longer vector lengths. Whereas G16 was a higher plant yielding and stable genotype because it has a short vector length (Figure 2).

When the biplot fits data perfectly, the cosine of the angel between two vectors represents the correlation between them. The vector length corresponds to discriminating ability (Yan and Kang 2003). The environments C5, C6, Y5, Y6, and S6 had longer vectors than other environments (Figure 3). Thus, they were the best environments for genetic differentiation of experimental hybrids. The most non-discriminating location was Bornova in both years for grain yield per plant. Also, the poorest 


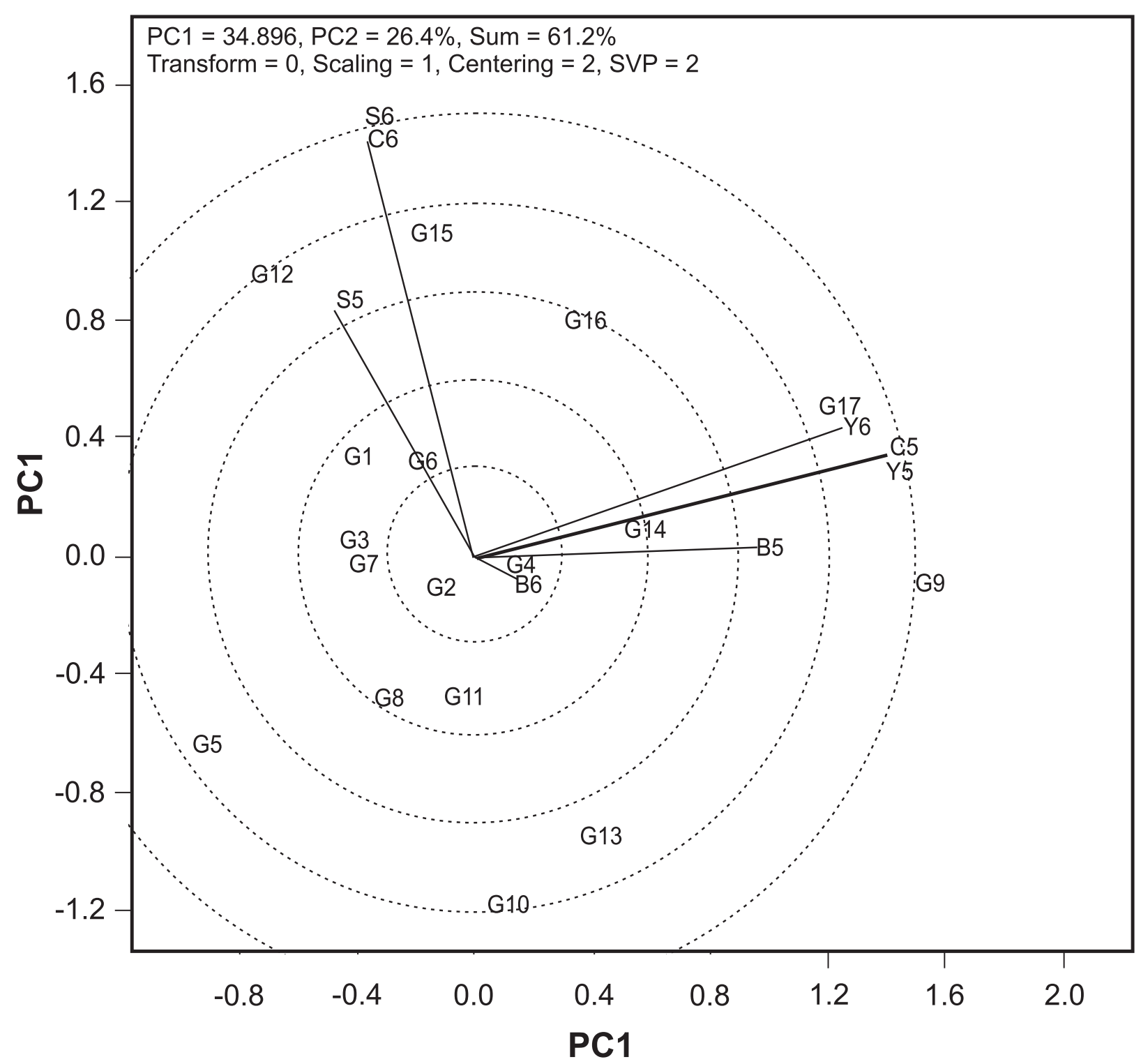

Figure 3. GGE-biplot based on genotype and environment focused scaling for comparison genotype and environments.

test environment relative to ideal environment was the Bornova location. Figure 3 indicated that the angles between the environmental vectors of $\mathrm{C} 5$ and $\mathrm{C} 6$ were fairly different. On the other hand, the angles between S5 and $\mathrm{S} 6$ or B5 and B6 or Y 5 and $\mathrm{Y} 6$ were quite similar. This situation demonstrated that these environments responded similarly for yield per plant in both years. Therefore, in our study, Yenişehir location (Y5 in 2005 and Y6 in 2006) was identified the best environment to select superior hybrid maize candidates for grain yield per plant in the maize breeding program.
There is severe competition among the private seed companies in hybrid seed marketing. Thus, all of the seed companies want to increase their market share in the hybrid maize seed market. Therefore, they have to develop their new hybrid cultivars as soon as possible. A vital goal in the breeding program is to provide reliable guidance for selecting the best genotypes for planting in future years and to predict yield as precisely as possible based on limited experimental data (Crossa et al. 1990). When considered from this point of view, the GGE biplot analysis as proposed by Balestre et al. (2009) is a useful tool for 
FA Tonk et al.

identifying test locations to select the superior experimental hybrids on maize breeding programs.

In our study, the GGE biplot analysis revealed G16 hybrids to be highly adapted to the test environments for grain yield per plant. In the present study, it appeared that the Yenişehir location as a test environment seems to be sufficient for deciding hybrid recommendation. However, Ilker et al. (2009) informed that the best test environment was determined as Ceyhan location considering grain yield per plot using the same genotypes. Furthermore, it was found that the highest yielding genotypes (G9, G17 and G16) among the hybrid maize candidates for grain yield per plant similar to those of high-yielding genotypes for grain yield per plot via GGE biplot analysis. Especially, G16 maize hybrid was determined to have both high grain yield and stability as it was indicated for grain yield per plot (Ilker et al. 2009). Therefore, for hybrid recommendation, using the grain yield per plant instead of grain yield per plot in hybrid maize breeding programs may have some advantages with respect to time consumption, labor and cost which are preferred by private companies. This information is expected to be beneficial for plant breeders of private companies in performance trials to identify the high yielding cultivars to use their limited resources economically.

\section{ACKNOWLEDGEMENTS}

We are grateful to Dr. Weikai Yan from Eastern Cereal and Oilseed Research Centre, Canada for analyzing our data with GGE biplot software and we gratefully acknowledge the collaboration of the MayAgro Seed Corporation.

\title{
Avaliação da interação genótipo $x$ ambiente em híbridos de milho usando análise GGE biplot
}

\begin{abstract}
RESUMO - Avaliaram-se 17 genótipos híbridos de milho na Turquia, em quatro diferentes locais e épocas de cultivo e sob irrigação, durante 2005 e 2006. A análise de variância revelou que os quadrados médios para ambientes $(E)$, genótipos $(G)$ e interação Gx Eforam altamente significantes e corresponderam a 74, 7 e $19 \%$ da soma de quadrados da combinação tratamentos, respectivamente. Os dados foram submetidos à análise de GGE biplot para se determinar os efeitos da interação Gx E na produção de grãos, O híbrido G16 revelou-se altamente produtivo nos locais de teste. Yenişehir se mostrou o mais representativo dos locais para tomada de decisão sobre a recomendação de híbridos experimentais. Por fim, a tomada da produção de grãos por planta ao invés da produção por parcela nos programas de melhoramento de híbridos de milho apresentou algumas vantagens e deve ser preferida pelas companies privadas.
\end{abstract}

Palavras-chave: milho, produção de grãos, mega-ambientes.

\section{REFERENCES}

Balestre M, Souza JC, Pinho RGV, Oliveira RL and Paes JMV (2009) Yield stability and adaptability of maize hybrids based on GGE biplot analysis characteristics. Crop Breeding and Applied Biotechnology 9: 219-228.

Boomsma CR, Santini JB, Tollenaar M and Vyn TJ (2009) Maize morphophysiological response to intense crowding and low nitrogen availability: an analysis and review. Agronomy Journal 101: 1426-1452.

Carena MJ (2005) Maize commercial hybrids compared to improved population hybrids for grain yield and agronomic performance. Euphytica 141: 201-208.

Comstock RE and Moll RH (1963) Genotype-environment interaction. In Statistical genetics and plant breeding. National Academy of Science/National Research Council, Washington, DC, p. 164-196 (Publication 982).
Crossa J (1990) Statistical analysis of multilocation trials. Advances in Agronomy 44: 55-85.

Dehghani H, Sabaghnia N and Moghaddah M (2009) Interpretation of genotype-by-environment interaction for late maize hybrids grain yield using a biplot method. Turkish Journal of Agriculture and Forestry 33: 1-10.

Fan XM, Kang MS, Chen H, Zhang Y, Tan J and XU C (2007) Yield stability of maize hybrids evaluated in multi-environment trials in Yunnan, China. Agronomy Journal 99: 220-228.

Gama EG and Hallauer AR (1980) Stability of hybrids produced from selected and unselected lines of maize. Crop Science 20: 623-626.

Giauffret C, Lothrop J, Dorvillez D, Gouesnard B and Derieux M (2000) Genotype $\mathrm{x}$ environment interaction in maize hybrids from temperature or highland tropical origin. Crop Science 40: 1004-1012. 
Ilke E, Tonk FA, Çaylak Ö, Tosun M and Özmen I (2009) Assessment of genotype $\mathrm{x}$ environment interactions for grain yield in maize hybrids using AMMI and GGE biplot analyses. Turkish Journal of Field Crops 14: 123-135.

Kang MS and Gorman DP (1989) Genotype x environment interaction in maize. Agronomy Journal 81: 662-664.

Kang MS, Gorman DP and Pham HN (1991) Application of a stability statistic to international maize yield trials. Theoretical and Applied Genetics 81: 162-165.

Kang MS (1998) Using genotype-by-environment interaction for crop cultivar development. Advances in Agronomy 62: 199252.

Kaya Y, Akçura M and Taner S (2006) GGE-biplot analysis of multienvironment yield trials in bread wheat. Turkish Journal of Agriculture and Forestry 30: 325-337.

Oliveira JP, Moreira WN, Duarte JB, Chaves LJ and Pinheiro JB (2003) Genotype-environment interaction in maize hybrids: an application of the AMMI model. Crop Breeding and Applied Biotechnology 3: 185-192.
Poehlman JM (1979) Breeding field crops. $2^{\text {th }}$ ed., AVI, Westport, Connecticut, 483p.

Scott GE (1967) Selecting for stability of yield in maize. Crop Science 7: 549-551.

Signor CE, Dousse S, Lorgeou J, Denis JB, Bonhomme R, Carolo P and Charcosset A (2001) Interpretation of genotype $x$ environment interaction for early maize hybrids over 12 years. Crop Science 41: 663-669.

Tollenaar M, Ahmadzadeh A and Lee EA (2004) Physiological basis of heterosis for grain yield in maize. Crop Science 44: 2086-2094.

Yan W (2001) GGE biplot: A windows application for graphical analysis of multi-environment trial data and other types of two-way data. Agronomy Journal 93: 1111-1118.

Yan W (2002) Singular value partitioning for biplot analysis of multienvironment trial data. Agronomy Journal 94: 990-996.

Yan W and Kang MS (2003) GGE biplot analysis: a graphical tool for breeders, geneticists and agronomists. CRC Press, Boca Raton, 271p. 